\title{
Cumulation and Anti-dumping: A Challenge to Competition
}

\author{
Thomas J. Prusa
}

\section{INTRODUCTION}

$\mathfrak{A}$

$S$ national economies have become increasingly inter-related, national governments have broadened their efforts to coordinate trade-related policies. For years GATT negotiators concentrated on tariff reduction and trade liberalisation. The recently completed Uruguay Round negotiations included a number of agreements in previously uncharted waters (e.g., agreements on government procurement, trade in services, and intellectual property).

Competition policy also emerged as an important area of interest during the later stages of Uruguay Round negotiations. Broadly speaking, competition policy is concemed with anti-competitive conduct; in an earlier era when markets were not as tightly integrated, domestic anti-trust policy was sufficient to enforce competition problems. However, in the modern trading environment, domestic laws are often insufficient to protect competition. Hence, the perceived need to incorporate international trade into competition policy. This task is complicated by the fact that there already are trade statutes - anti-dumping, countervailing duty, safeguard actions - that relate to issues of competition. While it is still an open question whether these laws will be incorporated into some sort of broadly defined competition policy, there can be little question that these trade statutes can have a significant impact on competition in domestic markets. Interestingly, this is not because they serve to promote competition but rather because they often seemed designed to reduce the effect of foreign competition on domestic producers.

The tension between the existing trade statutes and competition policy is most probably most clearly evidenced by anti-dumping law, the most widely used trade statute. As currently implemented anti-dumping (AD) law is designed to protect domestic producers while competition law is aimed at

THOMAS J. PRUSA is an Associale Professor at Rutgers University, New Brunswick, New Jersey and Facully Research Fellow, NBER. 
protecting domestic consumers. ${ }^{1}$ Moreover, many of the recent amendments to AD seemed aimed at making the statute even more producer biased. In this paper I will concentrate on how one specific amendment, the cumulation provision, clearly makes $A D$ an anti-competitive law and exemplifies the challenges that face those policy-makers who hope to move toward an economically justified competition policy.

The next section reviews US $A D$ procedures and how the cumulation amendment affects the injury investigation. Sections 3 and 4 examine how cumulation has affected filing patterns. Evidence will show that cumulation has led to more multiple petition filings and to smaller competitors being named. Section 5 discusses findings regarding the extent to which cumulation has altered the ITC's decision making. It argues that cumulation has changed the outcome (from negative to affirmative) in dozens, and possibly hundreds, of cases. Given all of these effects, cumulation should be viewed as a significant obstacle to those interested in assimilating $\mathrm{AD}$ law into the broader notion of competition policy.

\section{BACKGROUND}

Under GATT/WTO rules, AD duties can only be levied after it has been determined that (1) an unfair practice has occurred and (2) the unfair practice has caused material injury to the domestic industry. In the US these determinations are handled by the Department of Commerce (DOC) and the US International Trade Commission (ITC), respectively. If both determinations are affirmative, GATT/WTO rules allow the imposition of an AD duty that is designed to counter the alleged dumping. ${ }^{2}$

GATT/WTO guidelines require that AD duties be levied on a country-specific basis. For example, if an AD duty is levied on carbon steel pipes from France, no additional duty is levied on Canadian or Japanese (or any other alternative supplier of) carbon steel pipes. Domestic industries have overcome this shortcoming by filing petitions against multiple importing competing countries. If a sufficient number of the foreign competitors are restricted by an $\mathrm{AD}$ order, $\mathrm{AD}$ protection is effectively made comprehensive.

Unfortunately, naming multiple countries is not necessarily a panacea for the domestic industry. The ITC always makes its decisions on a country-by-country basis even if multiple countries are named. For example, if seven countries are named in a petition, the ITC will make seven separate injury decisions. And,

\footnotetext{
While it is possible for producers and consumers to have the same interests, say if anti-dumping required proof of predatory dumping, it is highly unlikely this is the case under current $A D$ rules.

2 About 25 per cent of cases have been withdrawn. As discussed in Prusa (1992) and Finger and Murray (1990), cases are generally withdrawn only after some type of agreement such as an orderly marketing arrangement, voluntary export restraint, elc.
} 
TABLE 1

Example of Cumulation

Brass Sheel and SIrip (Case Nos. 311-317)

\begin{tabular}{lcccc}
\hline Country & $\begin{array}{c}\text { Import Market } \\
\text { Share } \\
\text { Per Cent }\end{array}$ & $\begin{array}{c}\text { Cumulated } \\
\text { Market Share } \\
\text { Per Cent }\end{array}$ & $\begin{array}{c}\text { Market Share of } \\
\text { Other Named } \\
\text { Countries } \\
\text { Per Cent }\end{array}$ & $\begin{array}{c}\text { LTFV Duty' } \\
\text { Per Cent }\end{array}$ \\
\hline West Germany & 21.27 & 38.35 & 17.08 & 8.87 \\
Brazil & 4.81 & 38.35 & 33.54 & 40.62 \\
France & 3.78 & 38.35 & 34.57 & 42.24 \\
Italy & 3.27 & 38.35 & 35.08 & 12.08 \\
South Korea & 2.20 & 38.35 & 36.15 & 7.17 \\
Canada & 1.83 & 38.35 & 36.51 & 8.10 \\
Sweden & 1.20 & 38.35 & 37.15 & 9.49 \\
\hline
\end{tabular}

under current ITC procedures the volume of dumped imports is a crucial factor in the ITC's decision making. In practice this means that the ITC rarely finds 'injury by reason of dumped imports' unless the import volume is substantial. Thus, it would seem that naming a multitude of small countries only raises the cost of the filing with little real hope of gaining protection.

This was indeed the case until 1984 when the US Congress enacted the cumulation amendment. This provision requires the ITC to cumulate imports when a trade dispute involves imports from multiple sources. ${ }^{3}$ Prior to 1984 , the ITC could use its discretion whether to cumulate. Without cumulation, imports are evaluated on a country-by-country basis; when cumulation is applied, the ITC aggregates all 'like' imports from all countries under investigation and assesses the combined impact upon the domestic industry. If the imports from individual foreign competitors are aggregated, the impact of foreign competition will be more significant. Therefore, it is more likely that the ITC will decide that the domestic industry has suffered material injury by reason of unfairly traded import - even if the imports are from many different countries, each having a very small import market share.

To clarify how cumulation works, consider the example given in Table 1. In March 1986, the US brass sheet and strip industry filed AD petitions against firms located in seven different countries: West Germany, Brazil, France, Italy, South Korea, Canada and Sweden. In January 1987 the DOC determined that each of the countries had indeed engaged in 'less than fair value' sales. The duties ranged from about 7 per cent to over 40 per cent. The affirmative LTFV determinations

3 The 1984 amendment stipulates that imports from multiple sources must be cumulated when three criteria are satisfied: (1) the imports must compete with one another and the domestic product, (2) the imports must be marketed within a reasonably coincidental period, and (3) the imports must be under investigation. 
meant that duties would be levied against any country whose imports were deemed by the ITC to have materially injured the US industry.

Without cumulation, the ITC would have separately evaluated the injury from each country's sales. Under the old rules it was far more likely that the ITC would find injury due to imports from West Germany, which accounted for over 20 per cent of all US brass sheet and strip imports, than imports from Canada or Sweden, each which had less than 2 per cent of the import market. However, since the cases were subject to cumulation, the ITC was required to assess the injurious impact of the imports from all named countries. For example, when determining whether dumped imports from France materially injured the US industry, the ITC could not merely evaluate the injurious effects of France's 3.78 per cent market share, but was required to factor in the additional 34.57 per cent market share from the other named countries. In February 1987, the ITC found that imports from each of the seven countries had injured the US industry.

\section{CUMULATION AND AD FILING PATTERNS}

In order to better understand the impact of mandatory cumulation, I first examine case filings. In Table 2 I give a breakdown of cases by outcome. I also tabulate the data depending on whether cumulation was used.

The data make it clear that prior to mandated cumulation, the ITC only rarely chose to cumulate: only 30 out of $235 \mathrm{AD}$ cases (or 13 per cent) were cumulated. Note also that during the early period cumulated cases were somewhat more likely to receive an affirmative ITC decision than non-cumulated cases ( 30 per cent versus 22 per cent). Both facts (low incidence of cumulation but apparently a favourable impact when cases were cumulated) help to explain why domestic industries lobbied so aggressively to make cumulation mandatory.

The desirability of the mandated cumulation becomes even more apparent when we look at the trends following 1984. In fact, the post-1984 patterns are dramatically different. Rather than being rare, cumulation becomes the norm. Between 1985 and 1994 (inclusive), 75 per cent of AD cases (367 of 490) involved cumulation. And, of the 367 cumulated cases, a remarkable 51 per cent were granted relief; by contrast, only 40 per cent of the non-cumulated cases received favourable ITC decisions.

Interestingly, comparing the pre- and post-mandatory cumulation totals, one notices that about the same number of cases have been filed per year during each sub-period: on average, about 45 cases were filed during 1980-1984 and 19851994. At first glance this suggests that mandatory cumulation has had little effect on filing behaviour.

However, the raw numbers hide cumulation's impact for a couple of reasons. First, note that the discretionary cumulation numbers are heavily influenced by 
TABLE 2

Anti-dumping Cases 1980-1994

\begin{tabular}{|c|c|c|c|c|c|c|}
\hline & \multicolumn{2}{|c|}{$\begin{array}{c}\text { Discretionary Cumulation } \\
1980-1984\end{array}$} & \multicolumn{2}{|c|}{$\begin{array}{c}\text { Mandatory Cumulation } \\
1985-1994\end{array}$} & \multicolumn{2}{|c|}{$\begin{array}{c}\text { Entire Sample } \\
1980-1994\end{array}$} \\
\hline & No Cumulation & Cumulation & No Cumulation & Cumulation & No Cumulation & Ctumulation \\
\hline Negative DOC & $\begin{array}{c}14 \\
(7 \%)\end{array}$ & $\begin{array}{c}1 \\
(3 \%)\end{array}$ & $\begin{array}{c}5 \\
(4 \%)\end{array}$ & $\begin{array}{c}3 \\
(1 \%)\end{array}$ & $\begin{array}{c}19 \\
(6 \%)\end{array}$ & $\begin{array}{c}4 \\
(1 \%)\end{array}$ \\
\hline Negative ITC & $\begin{array}{c}66 \\
(32 \%)\end{array}$ & $\begin{array}{c}10 \\
(33 \%)\end{array}$ & $\begin{array}{c}48 \\
(39 \%)\end{array}$ & $\begin{array}{c}136 \\
(37 \%)\end{array}$ & $\begin{array}{c}114 \\
(35 \%)\end{array}$ & $\begin{array}{c}146 \\
(37 \%)\end{array}$ \\
\hline Aftirmative & $\begin{array}{c}45 \\
(22 \%)\end{array}$ & $\begin{array}{c}9 \\
(30 \%)\end{array}$ & $\begin{array}{c}49 \\
(40 \%)\end{array}$ & $\begin{array}{c}189 \\
(51 \%)\end{array}$ & $\begin{array}{c}94 \\
(29 \%)\end{array}$ & $\begin{array}{c}198 \\
(50 \%)\end{array}$ \\
\hline Wilhdrawn & $\begin{array}{c}80 \\
(39 \%)\end{array}$ & $\begin{array}{c}10 \\
(33 \%)\end{array}$ & $\begin{array}{l}21 \\
(17 \%)\end{array}$ & $\begin{array}{l}39 \\
(11 \%)\end{array}$ & $\begin{array}{l}101 \\
(31 \%)\end{array}$ & $\begin{array}{c}49 \\
(12 \%)\end{array}$ \\
\hline TOTAL & 205 & 30 & 123 & 367 & 328 & 397 \\
\hline
\end{tabular}

TABLE 3

Anti-dumping Filings 1980-1994

\begin{tabular}{|c|c|c|c|c|}
\hline \multirow{2}{*}{$\begin{array}{c}\text { No. of } \\
\text { Cases } \\
\text { in Filing }\end{array}$} & \multicolumn{2}{|c|}{$\begin{array}{c}\text { Discretionary Cumulation } \\
1980^{-}-1984\end{array}$} & \multicolumn{2}{|c|}{$\begin{array}{c}\text { Mandatory Cumulation } \\
1985-1994\end{array}$} \\
\hline & No Cumulation & Cumulation & No Cumulation & Cumulation \\
\hline 1 & 83 & 1 & 118 & 0 \\
\hline 2 & 15 & 5 & I & 39 \\
\hline 3 & 8 & 1 & $i$ & 18 \\
\hline 4 & 3 & 1 & 0 & 14 \\
\hline 5 & 3 & 1 & 0 & 3 \\
\hline 6 & 2 & 0 & 0 & 4 \\
\hline 7 & 3 & 1 & 0 & 4 \\
\hline 8 & 1 & 0 & 0 & 4. \\
\hline 9 & 0 & 0 & 0 & 4 \\
\hline$>9$ petitions & 0 & 0 & 0 & 3 \\
\hline Total number of filings & 118 & 10 & 120 & 93 \\
\hline Total number of cases & 205 & 30 & 123 & 367 \\
\hline Avg. number of cases per filing & 1.74 & 3.00 & 1.03 & 3.95 \\
\hline
\end{tabular}

the steel industry's large scale petitioning during in 1982 and 1984. If we drop the $\mathrm{AD}$ cases involving the steel industry, about 25 per cent more cases are filed per year post-1984. Second, the impact of cumulation on filing behaviour need not necessarily be evidenced in the total number of cases filed, but rather should be most clearly evidenced by the number of countries named in each filing.

To address this second issue, I tabulated the number of cases per filing (Table 3). Under both the old rules (i.e., discretionary cumulation) and the new rules (i.e., mandatory cumulation) an industry could choose to file more than a single $\mathrm{AD}$ case. 
For instance, in the brass sheet and strip filing discussed in Table 1, the steel industry chose to file seven cases. One would expect that under the old rules, industries would have less an incentive to name multiple competitors since each country's trade volume would be assessed separately. Under the new rules, however, naming multiple countries becomes a more profitable strategy. For instance, consider an industry that is ready to file an $\mathrm{AD}$ petition against country $x$ and $y$ that have 15 per cent and 10 per cent of the import market, respectively. Is it worthwhile for the industry to also name country $z$ that has 3 per cent of the import market? Under the old rules, injury would depend on country $z$ 's size (of course, many other factors enter into the injury decision in addition to market size). Moreover, as we will see later, the probability of winning a case against a country with only 3 per cent of the import market is rather small (about 15 per cent). Under the new rules, however, country $z$ would be evaluated as if it had 28 per cent of the import market.

Consider first the period 1980-1984 and those cases where cumulation was not applied. There were 205 petitions filed and 118 separate filings. Most of the filings (83) involved only a single country, 15 involved two countries, 8 involved three countries, and just a handful involved four or more countries. To summarise, under the old rules 70 per cent of non-cumulated filings involved only a single country.

By contrast, consider now the 30 cases where cumulation was applied. Industries applied for relief in 10 separate filings, implying an average of three countries per filing. More than half the 30 cases are accounted for by just three filings. ${ }^{4}$

Recall that Table 2 indicated that during the 1980-1984 period there was a rather low incidence of cumulated cases. This low incidence could be due either to the fact that industries were reluctant to file multiple petitions or to the fact that the ITC was hesitant to use their discretion and cumulate multiple petition filings. The data in Table 3 suggests that the former explanation is not the primary reason for the lack of cumulated cases. If the ITC had cumulated in all multiple petition filings, 35 additional filings would have been cumulated. Had all multiple petition filings been cumulated the filing patterns would look quite different: only 83 cases would have not been cumulated, and 152 cases would have been cumulated.

A couple of other interesting patterns emerge when we look at filing patterns once cumulation was made mandatory in 1984. First, once the ITC's discretion is eliminated, almost all multiple country petitions were cumulated. In fact, by my tabulation, only two multiple country petitions were not cumulated.

Second, most $\mathrm{AD}$ cases are part of a multiple country filing. This was also the case when cumulation was discretionary, but the evidence is even more striking

4 It is a bit odd that a cumulated filing could contain a single country. In 1984 the steel industry filed AD petitions against 'Welded carbon steel pipe and tube' from Taiwan and Singapore. Given the differences in the filing dates, the ITC chose to cumulate when determining injury against Taiwan, but decided not to cumulate when determining injury against Singapore. 
following 1984. Under the new rules, only 123 cases were filed where cumulation was not invoked. Of these, 118 involved only a single country. By contrast, only 93 filings account for the 367 cases that were filed where cumulation was invoked, On average, almost four countries were named in each filing. This is clear evidence that cumulation has had an important impact on filing behaviour.

Overall, about 1.8 countries were named per filing during the discretionary era and about 2.3 countries during the mandatory cumulation era. If we suppose that each filing during the post-1984 period named only 1.8 countries (i.e., that filing patterns post-1984 were similar to those during the discretionary period), we estimate that about $380 \mathrm{AD}$ cases would have been filed post-1984. In fact, 490 $\mathrm{AD}$ cases have been filed. While this is only a 'back of the envelope' estimate, it does imply that about 100 countries have been named in $\mathrm{AD}$ investigations during the mandatory cumulation era that would not have been named during the discretionary era.

\section{CUMULATION AND THE SIZE OF NAMED COUNTRIES}

At the time they were lobbying Congress to mandate cumulation US industries never emphasised that it would allow them to name more countries. That fact was really a side issue. Instead, industries emphasised that mandated cumulation would allow them to defend themselves from the so-called 'hammering effect' or 'death by one hundred blows.' One interpretation of this is that cumulation would allow domestic industries to file cases against smaller competitors.

In order to evaluate this aspect, I tallied import market shares of countries named in $\mathrm{AD}$ petitions. I report the statistics in Tables 4 and 5 . In both tables I report data for both non-cumulated and cumulated cases. Looking first at Table 4 notice that on average in non-cumulated cases the named country has about 24 per cent of the import market. By contrast, for cumulated cases the average named country only has about 14 per cent of the market. The median import market share for both groupings is smaller, but the relative magnitude is unaffected: whether measured by mean or median, the typical named country in cumulated cases is about half the size of those named without cumulation.

In Table $5 \mathrm{I}$ present an alternative way of capturing how cumulation has led to smaller competitors being named. In the top part of the table I report the per cent of named countries who have a market share greater than a given cut-off. For instance, 91 per cent of non-cumulated cases and 86 per cent of cumulated cases had a market share greater than one per cent. Thus, industries are somewhat more likely to name countries with very small import market shares when such countries can be cumulated with other competitors. The pattern is also seen at other cut-offs. In fact, the percentage of cumulated cases meeting any given cut- 
TABLE 4

Import Market Share Statistics

\begin{tabular}{lcc}
\hline & No Cumulation & Cumulation \\
\hline Import market share per case (\%) & & \\
Average & 24.0 & 13.5 \\
Median & 12.7 & 6.7 \\
Avg. number of countries per filing & 1.38 & 3.85 \\
Import market share per filing (total) (\%) & & \\
$\quad$ Average & 32.6 & 50.6 \\
Median & 24.6 & 51.7 \\
\hline
\end{tabular}

TABLE 5

Import Market Share (named country) 1980-1994

\begin{tabular}{ccc}
$\begin{array}{c}\text { Per Cent of Cases with } \\
\text { Import Market Share }>=\end{array}$ & $\begin{array}{c}\text { No Cumulation } \\
\text { Per Cent }\end{array}$ & $\begin{array}{c}\text { Cumulation } \\
\text { Per Cent }\end{array}$ \\
\hline 1 & 90.58 & 86.08 \\
2 & 82.07 & 74.15 \\
3 & 77.20 & 67.05 \\
5 & 68.69 & 56.53 \\
10 & 54.10 & 40.91 \\
15 & 45.29 & 30.97 \\
20 & 39.82 & 24.43 \\
\hline Per Cent of Filings with Total & No Cumulation & Cumulation \\
Import Market Share $>=$ & Per Cent & Per Cent \\
\hline 1 & 93.22 & 97.87 \\
2 & 87.29 & 96.81 \\
3 & 83.90 & 94.68 \\
5 & 79.66 & 92.55 \\
10 & 66.95 & 89.36 \\
15 & 57.20 & 86.17 \\
20 & 50.85 & 82.98 \\
\hline
\end{tabular}

off is smaller than the corresponding per cent of non-cumulated cases. No matter the import market share cut-off of cumulated cases tend to involve smaller countries.

Interestingly, while the individual countries are smaller in cumulated filings, the total amount of imports under investigation is larger. In other words, cumulation allows the domestic industry to name a larger fraction of its import competition. For instance, referring back to the brass sheet and strip example mentioned in Table 1, the import market share of the individual countries ranged from 21 per cent to I per cent, with an average import market share of 5.5 per cent. Overall, however, the entire filing accounts for over 38 per cent of the import market. 
I also calculated the overall import market share for all countries in a filing, and present the results in Tables 4 and 5. In Table 4 I tabulate the average import market share for a filing. I find that the typical non-cumulated filings investigate about 32 per cent of the import market. By contrast, about 50 per cent of the import market is investigated in cumulated filings.

In the bottom half of Table $5 \mathrm{I}$ calculate the per cent of filings where the total import market share is above a specified cut-off. For instance, 90 per cent of the cumulated filings have an import market share greater than 10 per cent; by contrast, only 67 per cent of the non-cumulated filings have an import market share greater than 10 per cent. As in the top half of the table, the pattern is robust to the choice of cut-off level of imports. Taking the results in Tables 4 and 5 together, it is clear that cumulation allows US industries to name smaller rivals but still have a large share of the import market potentially sanctioned by AD duties.

\section{CUMULATION AND ITC DECISIONS}

We now tum to the issue of whether cumulation has altered injury determinations. From Tables 4 and 5 we know that cumulated cases are typically filed against countries with small shares of the import market; this would seem to imply that cumulated cases are less likely to be successful. But, from Table 2 we know that injury is somewhat more likely to be found in cumulated cases than in non-cumulated cases. Taken together, these facts suggest that cumulation leads the ITC to be more protective.

The tabulations in Table 6 help to clarify these points. Once again I tabulate cumulated and non-cumulated cases separately. In this table I calculate ITC rejection rates for the cases as a function of the import market share under investigation. For instance, consider an import market share cut-off of five per cent. For non-cumulated cases with import market shares below this cut-off (the top-half of the table) the rejection rate is more than 75 per cent. In other words, the ITC has rejected three out of four non-cumulated cases when the named country has less than five per cent of the import market. By contrast, for cumulated cases with import market shares of less than five per cent, the rejection rate is about 50 per cent. Countries with small import market shares do worse when they are cumulated. Once again, this finding is robust to the choice of cutoff level.

The bottom part of the table reveals that cumulation also has a detrimental effect for countries with large import market shares. Consider once again the five per cent cut-off level. Countries with import market shares greater than five per cent are rejected by the ITC only 30 per cent of the time if they are part of a cumulated filing, but are rejected about 50 per cent of the time if they are not cumulated. 
TABLE 6

ITC Rejection Rates 1980-1994

\begin{tabular}{ccc}
\hline $\begin{array}{c}\text { Per Cent Rejection Rate for Cases with } \\
\text { Import Market Share }<=\end{array}$ & $\begin{array}{c}\text { No Cumulationt } \\
\text { Per Cent }\end{array}$ & $\begin{array}{c}\text { Cumulation } \\
\text { Per Cent }\end{array}$ \\
\hline 1 & 82.35 & 65.12 \\
2 & 82.14 & 59.26 \\
3 & 83.33 & 53.92 \\
5 & 76.47 & 54.07 \\
10 & 74.03 & 49.20 \\
15 & 70.53 & 46.82 \\
20 & 67.27 & 45.64 \\
\hline Per Cent of Filings with Total & & Cumulation \\
Import Market Share $>=$ & No Cumulation & Per Cent \\
\hline 1 & Per Cent & 37.50 \\
2 & 53.89 & 35.12 \\
3 & 52.20 & 35.29 \\
5 & 50.57 & 31.91 \\
10 & 49.69 & 30.15 \\
15 & 45.86 & 29.13 \\
20 & 44.35 & 28.05 \\
\hline
\end{tabular}

But, we must careful before concluding that it is cumulation that is making the ITC more protective. It is possible that there are other factors that have improved the domestic industries' cases. For instance, if $\mathrm{AD}$ cases have been filed during periods of bad macroeconomic performance (say, slow GDP growth) or during periods of heightened trade tensions, then cumulation might have little to do with the increased protection. Alternatively, domestic industries may have learned that having their Senators and Representatives lobby the ITC is an effective way to win cases. Or, the various amendments to the AD statute may have made the ITC more protective either by leading to larger LTFV margins or by other issues related to the injury decision. If we do not control for the effect of these factors separately from cumulation we cannot be sure what the injury determination would have been without cumulation.

Broadly speaking, we would like to predict the ITC's decision in case $i\left(\mathrm{INJ}_{i}\right)$ as a function of variables measuring the domestic industry's economic health $\left(\mathrm{H}_{i}\right)$, the state of the macroeconomy $\left(\mathrm{M}_{i}\right)$, political pressures $\left(\mathrm{PP}_{i}\right)$, and other miscellaneous pressures $\left(\mathrm{O}_{i}\right)$ such as the tariff rate, general trade patterns, etc. Finally, we would include a variable that measures the impact of cumulation $\left(\mathrm{C}_{i}\right)$. That is:

$$
\mathrm{INJ}_{i}=\left(\mathrm{H}_{i}, \mathrm{M}_{i}, \mathrm{PP}_{i}, \mathrm{O}_{i}, C_{i}\right),
$$

where $\mathrm{INJ}_{i}$ is a binary variable indicating whether the ITC rejected $(0)$ or accepted (1) the case. If cumulation makes the ITC more protective, we would expect the coefficient on $\mathrm{C}_{i}$ to be positive and significant. 
Hansen and Prusa (1996) have followed this approach in their study of how cumulation has affected the decision-making behaviour of the ITC. ${ }^{5}$ Their econometric approach incorporated both economic and political factors that may affect whether an AD petition receives protection. Specifics of the variables used to measure these effects are detailed in Hansen and Prusa (1996).

Briefly stated, the economic measures of injury are largely taken from statutory guidelines in US trade law. The ITC is directed to take into account the economic situation of an industry in determining injury, which we captured by the percentage changes in industry capacity utilisation and shipments. We also included both the LTFV margin and the named country's import market share as independent variables. Finally, we used two different measures to capture the effect of cumulation. One measure is a dummy variable $(=1$ when the case is cumulated). While this is a straightforward measure, it does not capture the fact that cumulation is likely to have a more significant effect on the outcome for named countries with small market shares. For example, in the brass sheet and strip filing, cumulation likely had a more significant impact on Canada and Sweden than West Germany. A second measure, the market share of the other named countries, captures the fact that cumulation is likely to be more important for countries with small import market shares.

The variables used to capture political pressure on the ITC range from general measures such as lost protection, overall market penetration, and the trade deficit; to specific political economy variables such as the number of oversight committee members' districts wherein the domestic industry operates and Political Action Committee (PAC) contributions to Senators and Representatives on Congressional oversight committees. We also controlled for the fact that steel and steel-related industries were by far the largest users of $\mathrm{AD}$ laws during the 1980s.

In Hansen and Prusa (1996) we use probit to estimate the equation. Interested readers should consult that paper for complete parameter estimates. In this paper I will only discuss the estimated importance of cumulation. In all specifications cumulation was estimated to have a statistically significant and positive effect (i.e., raise the likelihood of finding injury). Since interpreting the parameter estimates in probit models is difficult, we also calculated what the cumulation estimates implied for the change in the probability of an affirmative injury determination. Based on our estimates we found that cumulation increases the probability of protection by about 30 per cent. In other words, everything else equal, the ITC is about 30 per cent more likely to find injury in cumulated cases.

Not surprising this implies that cumulation crucially determines whether protection is granted in a large number of cases. Using these estimates we can also determine when cumulation was the crucial factor in leading the ITC to find

\footnotetext{
5 Tharakan, Greenaway and Tharakan (1998) find that cumulation has had a similar impacl on European Community injury decisions.
} 
injury. I found that cumulation changes the outcome somewhere between from 20 to 50 per cent of the time. Recall from Table 2 that 397 cases have been cumulated, and of these the ITC found injury in about 200 cases. If we use an implied effect in the middle of the range, say one-third of the cumulated cases outcomes change, our probit estimates imply that well over 60 cases resulted in $\mathrm{AD}$ duties due solely to cumulation. Clearly, cumulation makes $\mathrm{AD}$ law far more protective.

\section{CONCLUSION}

In this paper I have examined how mandatory cumulation has affected the use of $\mathrm{AD}$ law. The country-specific nature of $\mathrm{AD}$ protection limited $\mathrm{AD}$ 's effectiveness. Prior to mandatory cumulation domestic industries found it difficult to argue that small competitors were causing injury. The 1984 cumulation amendment solved the problem. With cumulation, multiple country petitions became an effective strategy since the import market share of all the named rivals would be summed when determining whether the volume of dumped imports was injurious.

Following the amendment, multiple country petitions have become the norm. Extrapolation from trends prior to the amendment suggest that cumulation has caused an extra 100 cases to have been filed over the past decade. Cumulated cases are also shown (1) to involve smaller competitors and (2) to be less likely to be rejected. Holding other factors constant, I estimate that cumulation has changed the ITC's determination in about 60 cases.

By increasing the number of cases filed and changing many outcomes, cumulation has made $\mathrm{AD}$ a much more protective statute. The time has come for mandatory cumulation to be recognised as harmful as some of AD's other better known problems (Boltuck and Litan, 1991; and Murray, 1991). While establishing international standards for competition policy is a lofty goal, policy-makers should not overlook the challenges to competition inherent in current AD rules. Substantial obstacles ranging from conflicting concepts of public interest to differing enforcement standards must be overcome before any type of WTO competition policy could be enacted. If policy-makers were truly interested in promoting competition, they would be well served by remedying the ills, as dramatically highlighted by mandatory cumulation, in the current $\mathrm{AD}$ rules.

\section{REFERENCES}

Boltuck, R. and R.E. Litan (1991), Down in the Dumps (Washington, DC: The Brookings Institution). 
Finger, J.M. and T. Murray (1990), 'Policing Unlair Imports: The United States Example', Journal of World Trade (August), 39-53.

Hansen, W.L. and T.J. Prusa (1996), 'Cumulation and ITC Decision-making: The Sum of the Parts is Greater than the Whole', Economic Inquiry, 34, 746-69.

Murray, T. (1991), 'The Administration of the Antidumping Duty Law by the Department of Commerce', in R. Boltuck and R.E. Litan (eds.), Down in the Dumps (Washington, DC: The Brookings Institution).

Prusa, T.J. (1992), 'Why are So Many Antidumping Petitions Withdrawn?', Journal of International Economics (August), 1-20.

Tharakan, P.K.M., D. Greenaway and J. Tharakan (1998), 'Cumulation and Injury Determination of the European Community in Antidumping Cases', Weltwirtschaftliches Archiv, 134, 2, 320-39. 